DIW BERLIN

Discussion Papers
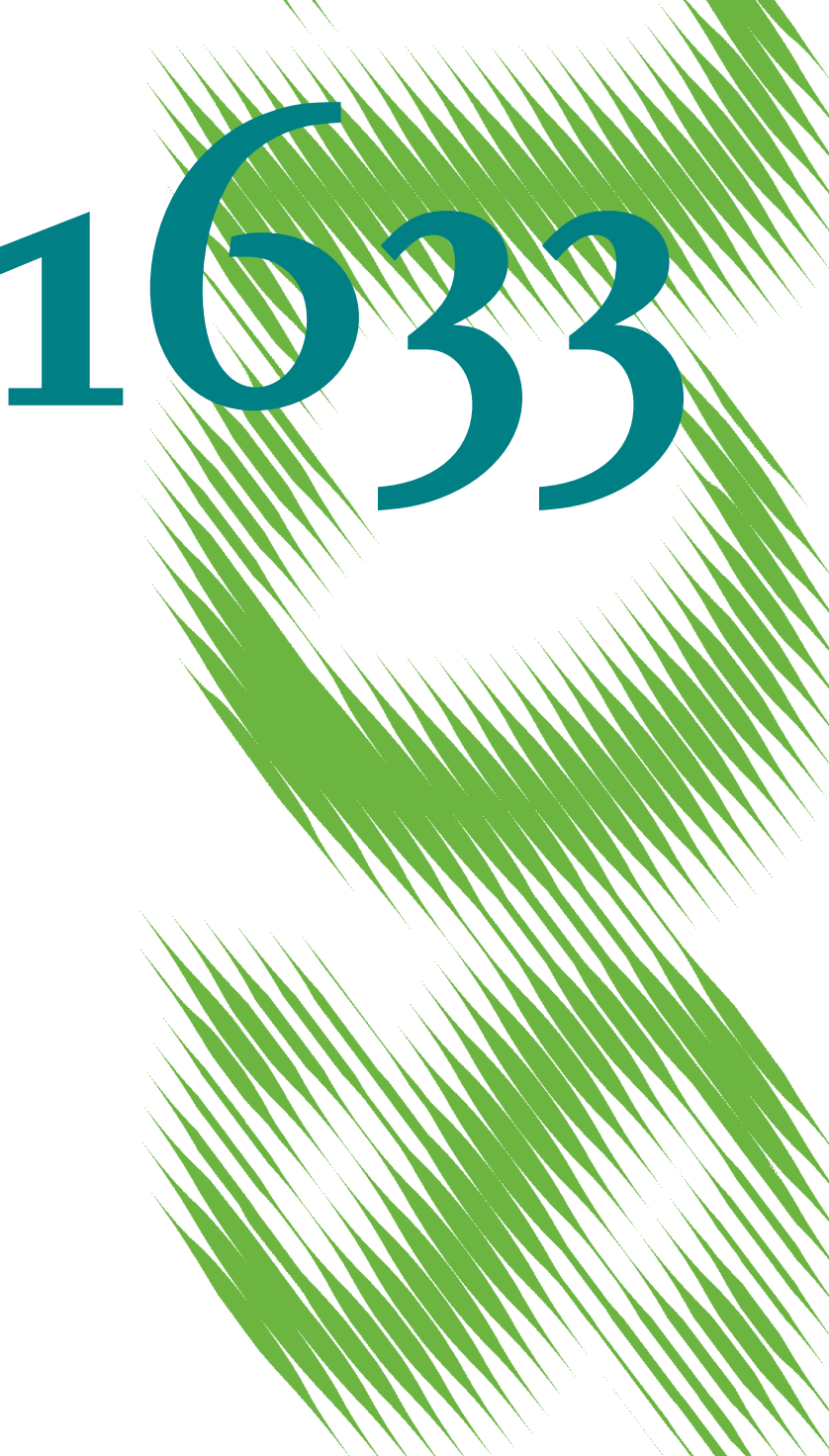

Austerity, Inequality and Private Debt Overhang 
Opinions expressed in this paper are those of the author(s) and do not necessarily reflect views of the institute.

IMPRESSUM

(C) DIW Berlin, 2017

DIW Berlin

German Institute for Economic Research

Mohrenstr. 58

10117 Berlin

Tel. +49 (30) $89789-0$

Fax +49 (30) $89789-200$

http://www.diw.de

ISSN electronic edition 1619-4535

Papers can be downloaded free of charge from the DIW Berlin website:

http://www.diw.de/discussionpapers

Discussion Papers of DIW Berlin are indexed in RePEc and SSRN:

http://ideas.repec.org/s/diw/diwwpp.html

http://www.ssrn.com/link/DIW-Berlin-German-Inst-Econ-Res.html 


\title{
Austerity, Inequality, and Private Debt Overhang*
}

\section{By Mathias Klein ${ }^{a}$ and Roland Winkler ${ }^{b}$}

${ }^{\text {a}}$ Corresponding author at DIW Berlin, Mohrenstraße 58, 10117 Berlin, Germany;

e-mail: mklein@diw.de

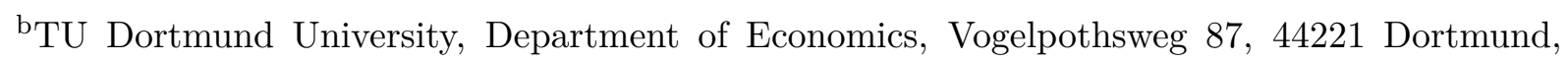
e-mail: roland.winkler@tu-dortmund.de

This version: January 17, 2017

\begin{abstract}
Using panel data of 17 OECD countries for 1980-2011, we find that the distributional consequences of fiscal consolidations depend significantly on the level of private indebtedness. Austerity leads to a strong and persistent increase in income inequality during periods of private debt overhang. In contrast, there are no discernible distributional effects when private debt is low. This result is robust to alternative identifications of fiscal consolidations, to different ways of defining periods of private debt overhang, and to controlling for the state of the business cycle. We explore different channels through which our findings can be rationalized.
\end{abstract}

Keywords: austerity, fiscal policy, inequality, private debt, local projections

JEL classifications: E62, E64, D63

\footnotetext{
${ }^{*}$ We thank Kerstin Bernoth, Christian Bredemeier, Christopher Krause, Ludger Linnemann, Michele Piffer, Malte Rieth and seminar participants at DIW Berlin for helpful comments and suggestions.
} 


\section{Introduction}

In the aftermath of the Global Financial Crisis, many governments implemented large-scale austerity programs in order to reduce budget deficits. This led to a renewed interest in how austerity affects the economy. While the average macroeconomic effects of fiscal consolidations are extensively investigated, ${ }^{1}$ the literature is exploring whether the effects of fiscal consolidations vary depending on the state of the economy (see, e.g., Jordà and Taylor 2016, Klein 2016, and Born, Müller, and Pfeifer 2015). These studies find evidence for strong and significant differences in the effects of fiscal consolidations on macroeconomic aggregates, depending on economic circumstances. Thereby, this literature helps inform policy discussions about when time is right for austerity.

Our paper extends this literature by showing that the distributional consequences of fiscal consolidations crucially depend on the presence of private debt overhang. ${ }^{2}$ Specifically, we find that austerity leads to a severe and significant increase in income inequality when private debt is high. In contrast, fiscal consolidations are associated with no discernible distributional consequences when private debt is low. Importantly, the distributional consequences of austerity are mainly determined by the presence of private debt overhang, whereas the state of the business cycle only plays a minor role. Our results imply that policy makers who are concerned about inequality should consider the level of private indebtedness when deciding if the time is right for implementing fiscal austerity measures.

Studying how policy changes affect the distribution of income across households is important for several key reasons. First, the aggregate effects of policy interventions cannot be fully understood without consideration of distributional dynamics. For example, consider a policy intervention that redistributes income across households. If those households gaining from the policy change have a higher marginal propensity to consume than those households losing, the redistribution itself offers a channel through which policy affects macroeconomic aggregates. Consequently, a new stream of literature jointly analyzes the aggregate and the distributional consequences of policy shocks in New Keynesian heterogeneous agent models. ${ }^{3}$ Our empirical findings provide conditional inequality responses that can be used as a target to differentiate between competing classes of heterogeneous agent models. Second, income inequality is linked to economic performance, political polarization, and financial market instability. The empirical debate on the inequality-growth nexus is still unsettled. Some papers find evidence that rising income inequality has negative consequences for economic growth (see, e.g., Alesina and Rodrik

\footnotetext{
${ }^{1}$ See, e.g., Alesina and Ardagna (2010) and Guajardo, Leigh, and Pescatori (2014).

${ }^{2}$ Throughout the paper, private debt overhang describes periods in which the ratio of private debt to GDP is above trend.

${ }^{3}$ See, e.g., Gornemann, Kuester, and Nakajima (2016), Auclert (2016), and Kaplan, Moll, and Violante (2016).
} 
1994 and Persson and Tabellini 1994), while there is competing evidence of beneficial effects (see, e.g., Barro 2000 and Li and Zou 1998). Moreover, there is evidence that inequality may have adverse consequences for socio-political stability, see, e.g., Alesina and Perotti (1996). Finally, some studies link rising income inequality to financial market instability and the likelihood of financial crisis, see, e.g., Kumhof, Rancière, and Winant (2015) or Kirschenmann, Malinen, and Nyberg (2016).

Focusing on how private indebtedness influences the inequality effects of austerity is motivated by the literature showing that private debt is of crucial importance for the propagation and amplification of shocks and policy interventions; see, e.g., Mian, Rao, and Sufi (2013), Jordà, Schularick, and Taylor (2013), and Schularick and Taylor (2012). Analyzing the interplay between private debt and fiscal policy, Eggertsson and Krugman (2012) and Andrés, Boscá, and Ferri (2015) show, using theoretical models, that the aggregate effects of government spending expansions are amplified by the level of private indebtedness. The rationale behind this lies in the presence of debt-constrained borrowers who have a higher marginal propensity to consume relative to non-constrained lenders. If the share of constrained households is sufficiently large, which corresponds to a high level of private indebtedness, Keynesian-multiplier effects emerge. Bernardini and Peersman (2015) provide empirical support for the relationship between the effectiveness of fiscal policy and private indebtedness. Using historical U.S. data, they show that the government spending multiplier is considerably larger in periods of private debt overhang. Klein (2016) presents multi-country evidence that the effects of fiscal consolidations on macroeconomic aggregates are elevated when private indebtedness is high. While all of these studies investigate how the aggregate effects of fiscal policy are affected by private indebtedness, to the best of our knowledge, this is the first paper studying the potentially important role of private debt in shaping the distributional consequences of fiscal policy interventions.

To investigate the effects of fiscal consolidations depending on the level of private indebtedness, we estimate state-dependent impulse responses of income inequality to exogenous changes in the government budget deficit using local projections, as suggested by Jordà (2005). We measure income inequality using the Gini index of disposable income. The estimated responses are allowed to vary according to the state of the private debt cycle, defined as fluctuations in the ratio of private debt to GDP around the trend. ${ }^{4}$ High-debt states and low-debt states are identified as periods when the ratio of private debt to GDP was above or below trend, respectively. Identification of fiscal consolidation is achieved by using the narrative measure proposed by Devries, Guajardo, Leigh, and Pescatori (2011), available for 1980-2009, which we extend to

\footnotetext{
${ }^{4}$ Throughout the paper, we use the terms "private debt cycle" and "credit cycle" interchangeably.
} 
include 2010 and 2011. The baseline dataset of our analysis covers a panel of 17 OECD countries from 1980 through 2011.

We find strong and statistically significant differences in the distributional consequences of austerity across debt states. A $1 \%$ of GDP reduction in the primary deficit translates into a rise in income inequality of 2 percentage points in high private debt states. In contrast, when private debt is low, the inequality effects of fiscal consolidations are found to be small and statistically indistinguishable from zero. Thus, an estimation approach that abstracts from debt-dependence may well lead to wrong policy conclusions.

We conduct various robustness checks that confirm our findings. In particular, we take into account possible anticipation effects due to fiscal foresight, we consider alternative ways of defining periods of private debt overhang, and we restrict our sample to the period before the Global Financial Crisis. Moreover, we rule out that our results are driven by the state of the business cycle. Inequality significantly increases in periods of private debt overhang, irrespective of whether the economy is experiencing a boom or a slump. Likewise, in booms and slumps, austerity has no discernible distributional consequences when private debt is low.

We explore three channels through which debt-dependent distributional consequences of fiscal consolidations can be rationalized: the earnings heterogeneity channel, the income composition channel, and the savings redistribution channel. These channels are found to be important in explaining the distributional consequences of monetary policy shocks by Coibion, Gorodnichenko, Kueng, and Silvia (2012). First, we show that fiscal consolidations lead to a significant decline in aggregate employment in high private debt states, while it reacts only marginally when private debt is low. This finding can be interpreted as a confirmation of the aforementioned theoretical contributions pointing out that the aggregate impact of fiscal policy interventions are larger during periods of private debt overhang. As employment losses fall disproportionately upon low income groups, labor earnings at the bottom of the distribution may be disproportionately affected (this is the earnings heterogeneity channel). Taken together, this can explain why income inequality rises during periods of private debt overhang. Second, we demonstrate that the share of income accruing to labor declines significantly in periods of private debt overhang, whereas it stays almost constant when private debt is low. For poorer households labor earnings represent the primary source of income, while richer households rely relatively more on capital income. The relative decline in labor income then tends to increase income inequality, even more so during periods of private debt overhang (income composition channel). Third, we find that the real interest rate increases if fiscal consolidations are implemented when private debt is high, while it barely responds when private debt is low. An unexpected increase in interest rates 
hurts borrowers and benefits savers. To the extent that borrowers are generally at the lower end of the income distribution, this tends to generate a more unequal income distribution (savings redistribution channel).

Our paper is related to the literature that, motivated by the significant widening of the income distribution in several countries since the 1980s, explores the distributional effects of monetary policy and fiscal policy, in general (see, e.g, Coibion, Gorodnichenko, Kueng, and Silvia 2012, Anderson, Inoue, and Rossi 2016, and Mumtaz and Theophilopoulou 2016), and fiscal consolidations, in particular (see, e.g., Agnello and Sousa 2014 and Ball, Furceri, Leigh, and Loungani 2013). However, none of these studies allows the effects to differ according to the state of the credit cycle. This is surprising given the aforementioned evidence suggesting that credit plays an important role in shaping economic fluctuations and the effects of policy interventions. In fact, we demonstrate that the inequality effects of fiscal policy vary considerably depending on the state of the credit cycle.

The remainder of the paper is organized as follows. Section 2 describes the data and the empirical strategy. Section 3 presents the main results and conducts various robustness checks. Section 4 explores mechanisms through which our results can be rationalized. The final section concludes.

\section{Econometric Method and Data}

We estimate state-dependent impulse responses to fiscal consolidations using local projections as proposed by Jordà (2005). This method is becoming an increasingly popular tool to estimate non-linear effects of policy interventions (see, for example, Auerbach and Gorodnichenko 2013, Ramey and Zubairy 2014 and Owyang, Ramey, and Zubairy 2013). The main advantages compared to VARs are that local projections are more robust to model misspecifications and the implicit dynamic restrictions involved in VARs are not imposed. Moreover, local projections offer a very convenient way to account for state dependence. ${ }^{5}$

For each horizon $k=0, \ldots, 4$, we estimate the following regression model:

$$
\begin{aligned}
Y_{i, t+k}-Y_{i, t-1}= & I_{i, t-1}\left[\beta_{H, k} D_{i, t}+\psi_{H, k} X_{i, t-1}\right] \\
& +\left(1-I_{i, t-1}\right)\left[\beta_{L, k} D_{i, t}+\psi_{L, k} X_{i, t-1}\right]+\alpha_{i, k}+\eta_{t, k}+\epsilon_{i, t+k},
\end{aligned}
$$

where $Y_{i, t+k}-Y_{i, t-1}$ is the change in income inequality at horizon $k, D_{i, t}$ is a fiscal consolidation shock, $\alpha_{i, k}$ are country fixed effects, $\eta_{t, k}$ capture time fixed effects, and $X_{i, t-1}$ is a vector of

\footnotetext{
${ }^{5}$ Note that the Jordà method does not uniformly dominate the standard VAR approach for calculating impulse responses. In particular, because it does not impose any restrictions that link the impulse responses across different horizons, the estimates are often erratic because of the loss of efficiency. Moreover, it sometimes displays oscillations at longer horizons. For a more detailed discussion, we refer to Ramey and Zubairy (2014).
} 
control variables. The dummy variable $I_{i, t-1}$ captures the state $\{H, L\}$ of private indebtedness prior to the shock, where $I_{i, t-1}=1$ if private debt is high. We include a one-period lag of $I_{i, t}$ in the regressions to minimize contemporaneous correlations between fiscal shocks and the state of the economy. Given our specification, $\beta_{H, k}$ provides the response of $Y_{i, t+k}-Y_{i, t-1}$ to the consolidation shock at time $t$ in high private debt states, whereas $\beta_{L, k}$ provides the response in low private debt states.

We use annual data of 17 OECD countries for 1980-2011. We measure income inequality using the Gini coefficient for disposable income from the Standardized World Income Inequality Database (SWIID), which is available through 2011. ${ }^{6}$ The SWIID incorporates data from various international and national sources in order to increase comparability of available inequality data (for more details, see Jenkins 2015). Our vector of control variables $X_{i, t-1}$ includes real GDP growth and the change in the Gini coefficient. To measure fiscal consolidations, we use the narrative series proposed by Devries, Guajardo, Leigh, and Pescatori (2011), available for 1980-2009, which we extend through 2011. The series contains only those changes in the primary balance to GDP ratio that are motivated by a desire to reduce the budget deficit. As shown by Guajardo, Leigh, and Pescatori (2014), the narrative measure is not correlated with the short-term economic outlook, thereby providing a series of exogenous discretionary changes in fiscal policy. In extending the narrative consolidation measure, we follow Dell' Erba, Mattina, and Roitman (2015) who provide data of the consolidation measure for 2010 and 2011. The extension of the dataset is based on the following two OECD reports: Restoring Public Finances, 2011 and Restoring Public Finances, 2012 Update. These reports outline the economic situation, fiscal consolidation strategy, and major consolidation measures for each OECD member country. The country notes in each report lay out each government's rationale for pursuing fiscal adjustment and are used to identify consolidation periods that were motivated by a desire for deficit reduction.

As indicator for private indebtedness, we use the ratio of private debt to GDP. A similar indicator is used by Schularick and Taylor (2012), and Jordà, Schularick, and Taylor (2013) to study the role of credit in shaping the business cycle. Private debt data are taken from the Bank for International Settlements's database on credit to the non-financial sector. To differentiate between high- and low-debt states, we filter the debt-to-GDP ratio by country-specific HP trends with smoothing parameter $\lambda=100$, which corresponds to the usual value used for annual observations in the business cycle literature (Hodrick and Prescott 1997). This choice is justified by evidence found studying the characteristics of the credit cycle. Using a private credit series

\footnotetext{
${ }^{6} \mathrm{~A}$ detailed description of the data and the data sources can be found in the Appendix.
} 
covering several advanced economies for over 150 years, Jordà, Schularick, and Taylor (2016) find that the average duration of a credit cycle is similar to the average duration of a traditional business cycle. However, in a later exercise, we show that our results are robust when using a smoother HP-trend.

We define high private debt states as periods with positive deviations of debt-to-GDP ratios from trend. Periods in which the private debt-to-GDP ratios are below trend indicate low private debt states. This procedure implies that out of the 544 periods included in the sample, 279 or $51 \%$ are detected as low private debt periods, while the remaining 265 episodes or $49 \%$ indicate periods of private debt overhang.

\section{Results}

This section presents our estimation results. First, we present evidence for private debtdependent effects of fiscal consolidations on income equality, based on our baseline specification. Second, we discuss a series of robustness checks for our baseline results, including an alternative identification scheme that controls for fiscal foresight, alternative debt state definitions, and an alternative measure of income inequality. Moreover, we show that our results are robust when leaving out the Global Financial Crisis years. Finally, we demonstrate that our results are robust to controlling for the state of the business cycle.

\subsection{Baseline Results}

Figure 1 displays the change in income inequality after fiscal consolidations. To facilitate the interpretation of the results, we normalize responses so that the cyclically-adjusted primary balance rises by one percentage point on impact. For comparison, the left panel shows responses based on a model with no state dependence. The middle and right panel show results from our baseline nonlinear estimation. The middle panel displays the change in income inequality during periods of private debt overhang, whereas the right panel shows responses when private debt is low. The solid lines correspond to the point estimates and the shaded areas indicate $90 \%$ confidence intervals based on Driscoll and Kraay (1998) standard errors. These standard errors are robust with respect to heteroskedasticity as well as serial and cross-sectional correlation. Numbers on the horizontal axes denote years after the shock and the responses are expressed in percentage points.

We begin by considering the distributional consequences of fiscal consolidations in the model with no state dependence. The left panel of Figure 1 displays a moderate increase in inequality 


\section{Figure 1: Effects of Fiscal Consolidations on Income Inequality.}
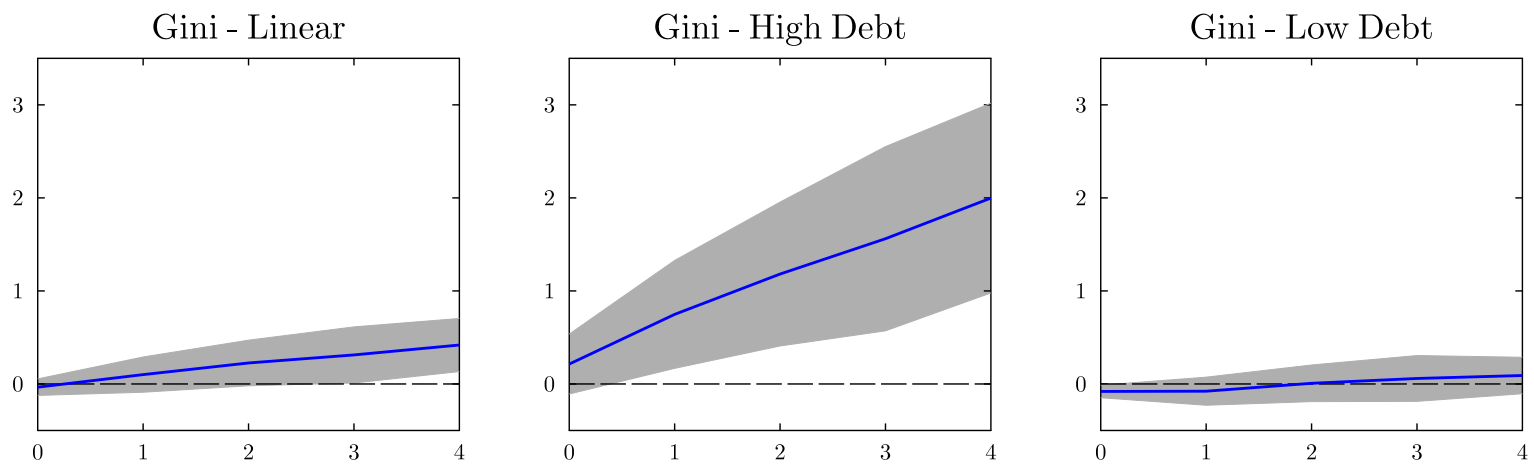

Notes: Changes in income inequality in response to a shock of $1 \%$ of GDP to the cyclically-adjusted primary balance over $k=0,1,2,3,4$ years. The shaded areas indicate $90 \%$ confidence bands based on Driscoll-Kraay standard errors.

that only becomes significant after around three years following the consolidation shock. At horizon $k=4$, the Gini coefficient increases by 0.42 percentage points. $^{7}$

The most interesting aspects are seen by comparing the responses across columns of Figure 1. It is evident that there are pronounced nonlinearities in the distributional consequences of fiscal consolidations, in the sense that the effects differ substantially across states of the private debt cycle. During periods of high private debt, fiscal consolidations lead to a strong and long-lasting rise in income inequality. Four years after the consolidation, the Gini coefficient increases by 2 percentage points. Thus, fiscal consolidations have a much larger adverse impact on income inequality during periods of private debt overhang than is predicted by a model abstracting from state dependence. In contrast, when private debt is low, fiscal consolidations are followed by hardly any change in income inequality. Note that the difference between the responses of income inequality, conditional on different debt states, is also statistically significant. Using a standard F-test, we can reject the null hypothesis of equal responses in high-debt states and low-debt states at the $5 \%$ level for horizons $k=1$ and $k=4$. For the remaining horizons, the coefficients across debt states are estimated to be significantly different at the $10 \%$ level.

In sum, our evidence suggests that the distributional consequences of fiscal consolidations vary considerably with the level of private indebtedness. This implies that an estimation approach ignoring debt-dependence may well lead to wrong policy conclusions.

\footnotetext{
${ }^{7}$ Ball, Furceri, Leigh, and Loungani (2013) present similar estimates based on local projections. However, because Ball, Furceri, Leigh, and Loungani (2013) report $68 \%$ confidence bands, their inequality response is statistically significant for all periods of the forecast horizon. As Figure 1 shows, statistical significance vanishes for most of the periods when relying on $90 \%$ confidence intervals.
} 
Table 1: Robustness (Effect in Year $k=1$ ).

\begin{tabular}{|c|c|c|c|}
\hline & High Debt & Low Debt & Difference \\
\hline Baseline & $\begin{array}{l}0.748^{* * *} \\
(0.353)\end{array}$ & $\begin{array}{c}-0.078 \\
(0.092)\end{array}$ & $0.826^{* * *}$ \\
\hline Alternative Identification & $\begin{array}{l}1.131^{* * *} \\
(0.559)\end{array}$ & $\begin{array}{c}-0.076 \\
(0.101)\end{array}$ & $1.207^{* * *}$ \\
\hline \multicolumn{4}{|c|}{ Alternative Debt States Definitions } \\
\hline$\lambda=1000$ & $\begin{array}{c}0.232^{* *} \\
(0.129)\end{array}$ & $\begin{array}{c}-0.096 \\
(0.159)\end{array}$ & $0.328^{* *}$ \\
\hline Smooth Transition & $\begin{array}{c}0.865^{* *} \\
(0.486)\end{array}$ & $\begin{array}{r}-0.119 \\
(0.121)\end{array}$ & $0.983^{* * *}$ \\
\hline Alternative Gini index & $\begin{array}{l}0.293^{* * *} \\
(0.097)\end{array}$ & $\begin{array}{c}-0.090 \\
(0.159)\end{array}$ & $0.383^{* * *}$ \\
\hline Leaving out GFC & $\begin{array}{c}0.367^{* *} \\
(0.215)\end{array}$ & $\begin{array}{c}-0.007 \\
(0.206)\end{array}$ & $0.373^{*}$ \\
\hline
\end{tabular}

Notes: The table reports point estimates and Driscoll-Kraay standard errors in parentheses. In each case the shocks are normalized so that the cyclically-adjusted primary balance rises by $1 \%$ of GDP in year $k=0$. ${ }^{*}$ Significant at $16 \% ;{ }^{* *}$ significant at $10 \% ;{ }^{* * *}$ significant at $5 \%$.

\subsection{Robustness}

We now re-specify our baseline empirical approach in order to check the robustness of our main result that the distributional consequences of fiscal consolidations vary considerably over the credit cycle.

For brevity, we report responses for horizon $k=1$ in tabular form (our main results are robust across alternative forecast horizons). The first line of Table 1 repeats our baseline results. Columns 2 and 3 display the estimated change in the Gini coefficient one year after the fiscal consolidation for high-debt states and low-debt states, respectively. Driscoll-Kraay standard errors are reported in parentheses. Column 4 reports the estimated difference across states. *, ${ }^{* *}$, or ${ }^{* * *}$ indicate significance at the $16 \%, 10 \%$, or $5 \%$ level. $^{8}$.

Alternative Identification. Jordà and Taylor (2016) question the exogeneity of the narrative measure. They argue that the Devries, Guajardo, Leigh, and Pescatori (2011) series has a predictable component. Therefore, our estimates could be biased when using the narrative measure as indicator for exogenous consolidation shocks.

To account for possible anticipation effects, we combine the approach suggested by Jordà and Taylor (2016) with the forecast error-approach proposed by Auerbach and Gorodnichenko

\footnotetext{
${ }^{8}$ The $16 \%$ level is chosen as lower threshold because $16-84 \%$ confidence bands are widely used in the empirical macro literature (see, for example, Castelnuovo and Surico 2010 and Hofmann, Peersman, and Straub 2012)
} 
(2012). ${ }^{9}$ The procedure consists of two steps. First, we regress the narrative consolidation measure, $D_{i, t}$, on a set of control variables that might include information that helps to predict the outcome variable (real GDP growth, change in cyclically-adjusted primary balance, change in the GDP deflator). The residuals of this regression measure the unpredictable component of fiscal consolidations. In a second step, the residuals are used as proxy for exogenous austerity innovations in the estimation of Equation (1).

The second row of Table 1 shows that we also find strong and significant differences in the distributional consequences of fiscal consolidations across the private debt cycle under this alternative identification scheme. Fiscal consolidations lead to a severe and significant increase in income inequality when private debt is high. In contrast, austerity is not associated with significant distributional consequences when private debt is low. Compared to our baseline specification, the difference between debt states is estimated to be larger when applying this alternative identification approach. ${ }^{10}$ This exercise shows that the finding of private debtdependent distributional effects of fiscal consolidation is robust to alternative ways of identifying fiscal consolidation episodes.

Alternative Debt States Definitions. We define high (low) private debt states as positive (negative) deviations of private debt-to-GDP ratios from (country-specific) HP trends. For our benchmark estimation, we set the smoothing parameter $\lambda$ equal to 100 , motivated by recent evidence showing that the average duration of the credit cycle is similar to the average duration of the business cycle (Jordà, Schularick, and Taylor 2016). In contrast to this evidence, Borio (2014) and Drehmann, Borio, and Tsatsaronis (2012) argue that the credit cycle is significantly longer and has a much greater amplitude than the standard business cycle. Therefore, Drehmann, Borio, and Tsatsaronis (2011) propose using a smooth HP-trend in order to capture the low frequency of credit cycles. To account for the possible longer duration of the credit cycle, we re-estimate Equation (1) but set $\lambda=1000$, which implies a relatively smooth HP-trend. Table 1 shows the results of this exercise. Our results are robust when allowing for a smoother trend. We again find significant differences in the distributional consequences of fiscal consolidations over the credit cycle. In periods of private debt overhang, income inequality increases significantly after fiscal consolidations, whereas income inequality is barely affected when private debt is low.

In our previous analysis, we defined any positive (negative) deviation from trend as a period of high (low) private debt. This definition of debt states does not take into account the scope of private debt overhang or the amplitude of the credit cycle. Figure 2 shows results of

\footnotetext{
${ }^{9}$ Auerbach and Gorodnichenko (2012) use the unpredictable component of government spending as proxy for exogenous variations in fiscal expenditures.

${ }^{10}$ This is consistent with Jordà and Taylor (2016), who find that the effects of fiscal consolidations on macroeconomic aggregates are amplified once they control for possible anticipation effects in the narrative measure.
} 


\section{Figure 2: Effects of Fiscal Consolidation on Income Inequality, Excessive Debt} Overhang.
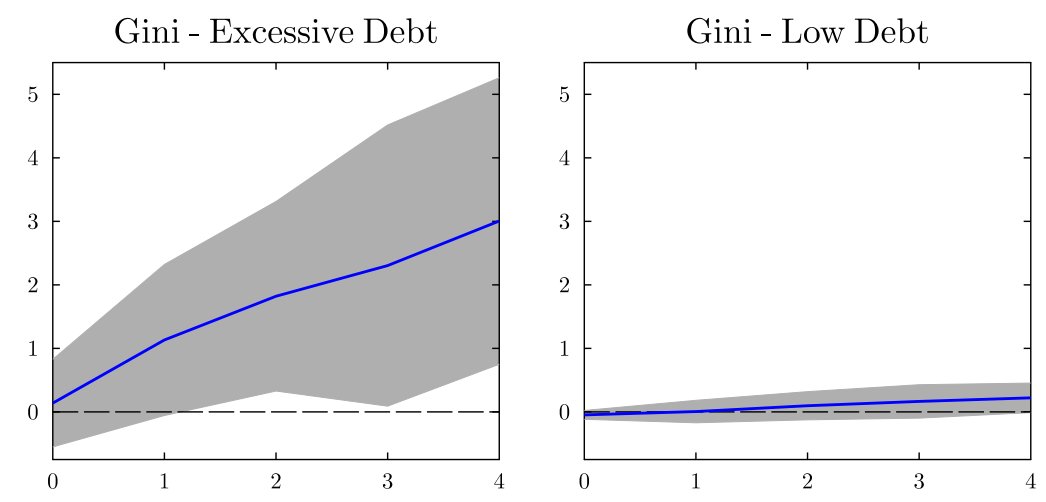

Notes: Changes in income inequality in response to a shock of $1 \%$ of GDP to the cyclically-adjusted primary balance over $h=0,1,2,3,4$ years. The shaded areas indicate $90 \%$ confidence bands based on Driscoll-Kraay standard errors.

an alternative definition of debt states in which we distinguish between periods with excessive debt overhang (defined as those debt to GDP deviations from trend that are larger than the country-specific mean of positive deviations from trend) and periods with lower debt. In periods of excessive debt overhang, we again find evidence for strong and significant distributional consequences of fiscal consolidations. Compared to our baseline specification, the point estimates are even more pronounced, but also more uncertain. Four years after the consolidation, the Gini coefficient increases by 3 (instead of 2 ) percentage points. Thus, the higher the level of private debt overhang, the more severe inequality is affected by fiscal consolidations. In low-debt states, though, austerity does not affect income inequality.

So far, our indicator variable $I_{i, t}$ was computed as a dummy variable, with observations 0 and 1. To account for a gradual regime change, we calculate a continuous indicator function based on the smooth-transition approach applied by several contributions studying state-dependent effects of policy interventions, see, e.g., Auerbach and Gorodnichenko (2013), Caggiano, Castelnuovo, Colombo, and Nodari (2015), and Tenreyro and Thwaites (2016). Table 1 shows the results of this exercise. ${ }^{11}$ As it turns out, the estimates are pretty similar to our baseline case. Consolidations implemented when private debt is high lead to a significant increase in income inequality, whereas austerity undertaken when private debt is low has no significant effect on inequality. In line with our benchmark results, the state-dependent coefficients are also estimated to be significantly different when relying on a smooth transition approach.

In sum, these exercises reveal that our findings do not rely on the specific method of defining low and high private debt states.

\footnotetext{
${ }^{11}$ Details on the calculation of the indicator function are presented in the Appendix.
} 
Alternative Gini index. So far, our results rely on the Gini index provided by the SWIID database. Although the SWIDD database offers data for most countries and for a substantial period of time, there are some concerns about its data comparability (see, e.g., Jenkins 2015). For this reason, we test whether our findings are robust when using an alternative time series for the Gini index. More specifically, we use the Gini index of the Estimated Household Income Inequality (EHII) Data Set built by the University of Texas Inequality Project. Unfortunately, this dataset is only available for the period 1980-2005 and just covers 15 out of the 17 countries of our baseline sample. Keeping this loss of information in mind, the second last row of Table 1 shows the results when using the EHII Gini index as dependent variable. As seen in the table, our finding of private debt-dependent distributional effects of fiscal consolidations holds true also when using this inequality measure.

Leaving out the Global Financial Crisis. The results presented so far are based on a sample that includes the Global Financial Crisis period and its aftermath in which private debt to GDP ratios were considerably above trend and in which large-scale austerity programs were undertaken. Thus, the question arises of whether our findings are mainly driven by Global Financial Crisis and its aftermath. To check, we remove observations from the Global Financial Crisis and its aftermath and then re-estimate our model on a sample ending in 2006. The last row of Table 1 shows that our main result remains intact. Austerity raises inequality when private debt is high, whereas we do not find discernible distributional consequences when private is low. ${ }^{12}$

\subsection{Controlling for the Business Cycle}

This paper emphasizes the credit-cycle dependency of the distributional consequences of austerity. Jordà and Taylor (2016) and Agnello and Sousa (2014) find that the aggregate and distributional effects of fiscal consolidations are amplified in periods of economic slack. Given this, it is possible that our emphasis on nonlinear effects across the credit cycle are simply a relabeling of nonlinear effects across the business cycle. This, however, is not the case as we show in the following.

\footnotetext{
${ }^{12}$ In an additional exercise, we investigate whether the results are driven by any key country in the sample. To do so, we have re-estimated Equation (1) by sequentially dropping one country at a time. We find that the baseline result is not driven by any key player in the sample. Results of these estimations are available upon request.
} 
To investigate the role of the business cycle for our results, we now differentiate between booms and slumps and estimate the following two specifications separately for low and high private debt states:

$$
\begin{aligned}
Y_{i, t+k}-Y_{i, t-1}= & I_{S, i, t-1}\left[\psi_{S, k}(L) X_{i, t-1}+\beta_{S, k} D_{i, t}\right] \\
& +I_{B, i, t-1}\left[\psi_{B, k}(L) X_{i, t-1}+\beta_{B, k} D_{i, t}\right] \\
& +I_{O, i, t-1}\left[\psi_{O, k}(L) X_{i, t-1}+\beta_{O, k} D_{i, t}\right] \\
& +\alpha_{i, k}+\eta_{t, k}+\epsilon_{i, t+k} .
\end{aligned}
$$

$I_{S, i, t}$ and $I_{B, i, t}$ now indicate the state of the business cycle within the respective private debt states. In the estimation for high private debt states, $I_{S, i, t}$ measures periods of high private debt that coincide with periods of economic contractions, whereas $I_{B, i, t}$ indicates periods of high private debt that are also characterized by economic expansions. $I_{O, i, t}$ is then a dummy variable for being in the opposing private debt state (low private debt) irrespective of the state of the business cycle. $\beta_{S, k}$ and $\beta_{B, k}$ then provide the state-dependent responses in slumps and booms within the high-debt regime, respectively. Analogously, in the estimation for low private debt states, $I_{S, i, t}\left(I_{B, i, t}\right)$ measures periods of low private debt that coincide with periods of economic slumps (booms) and $I_{O, i, t}$ indicates periods of high private debt.

We define booms and slumps in two ways. First, we consider the output gap as an indicator of the state of the business cycle. More precisely, we follow Jordà and Taylor (2016) and define booms (slumps) as positive (negative) deviations of log real GDP from country-specific HP trends, where we use a smoothing parameter of $\lambda=100$. Second, similar to Ramey and Zubairy (2014) we use the detrended unemployment rate as an indicator of economic slack. ${ }^{13}$

Figure 3 shows that our results appear in both business cycle states. ${ }^{14}$ If private debt is high, inequality increases significantly, irrespective of the state of the business cycle. Likewise, if private debt is low, consolidations do not significantly impact income inequality, neither during booms nor during slumps. This holds irrespective of whether we identify booms and slumps via the output gap, see Figure 3(a), or via the detrended unemployment rate, see Figure 3(b).

Figure 3 also makes clear that economic slumps amplify the adverse distributional consequences of fiscal austerity during high private debt states, compared to periods in which economic activity is booming. This is particularly evident if economic slumps are identified using the unemployment rate. Most importantly, there are no adverse distributional consequences when private debt is low, irrespective of whether the economy is experiencing a boom or a slump.

\footnotetext{
${ }^{13}$ We again compute country-specific HP trends with a smoothing parameter $\lambda=100$.

${ }^{14}$ Due to the limited observations of each of the four regimes (high debt/slump, high debt/boom, low debt/slump, low debt/boom), Figure 3 presents $68 \%$ confidence bands.
} 
Figure 3: Controlling for the Business Cycle.

(a) Output gap
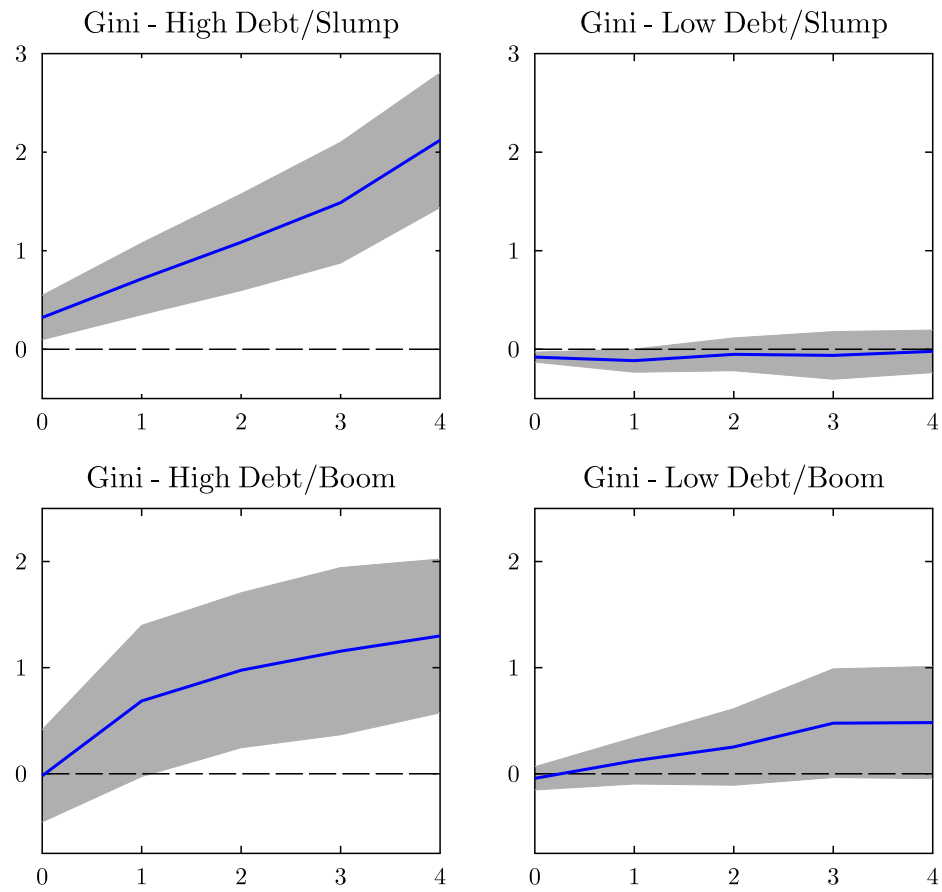

(b) Unemployment
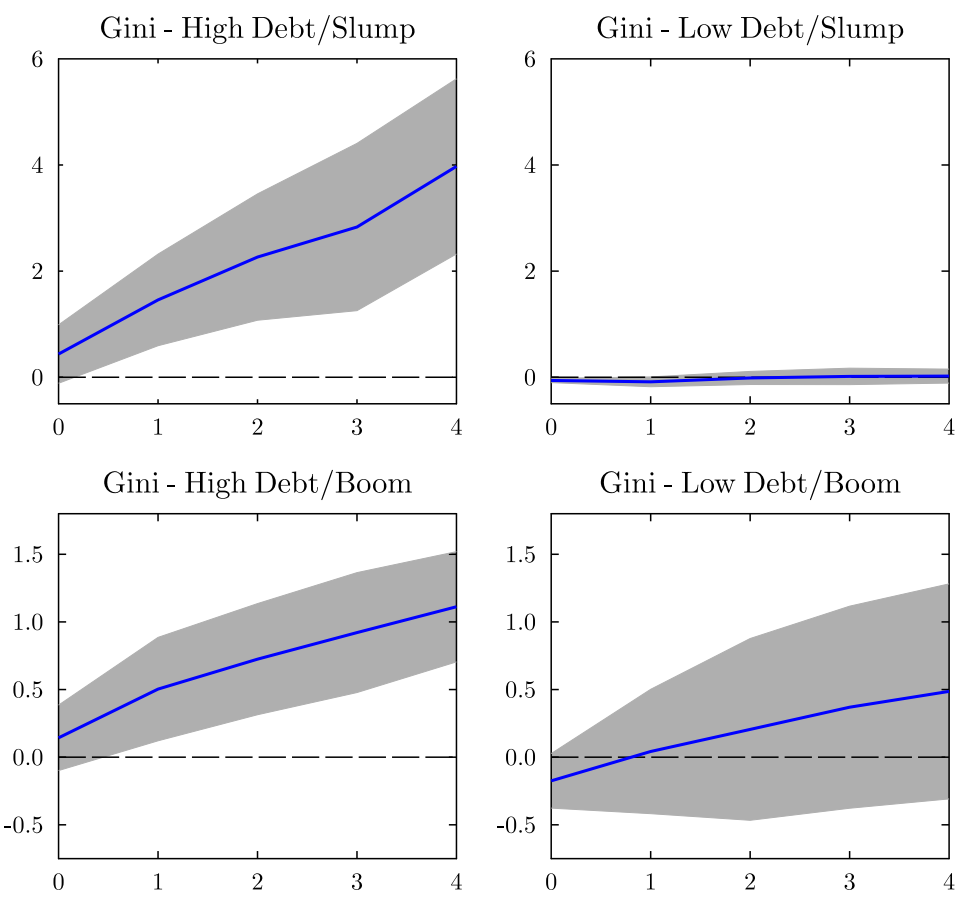

Notes: Changes in income inequality in response to a shock of $1 \%$ of GDP to the cyclically-adjusted primary balance over $h=0,1,2,3,4$ years. The shaded areas indicate $68 \%$ confidence bands based on Driscoll-Kraay standard errors. 
Interestingly, when private debt is low, the point estimates associated with economic expansions are even larger than the respective slump-estimates, although the coefficients are not statistically different from zero. In sum, our results suggest that the distributional consequences of austerity are mainly determined by the level of private indebtedness in the economy, whereas the state of the business cycle seems to play a minor role for the inequality effects of fiscal consolidations.

\section{Potential Explanations}

The evidence shown in the previous section suggests that the distributional consequences of fiscal consolidations crucially depend on the state of the credit cycle. We now investigate potential mechanisms underlying the debt-dependent inequality responses. Specifically, we highlight the role of three distinguished channels through which our results can be rationalized: the earnings heterogeneity channel, the income composition channel, and the savings redistribution channel. ${ }^{15}$

Earnings heterogeneity channel. Labor earnings are the primary source of income for most households. The earnings heterogeneity channel explains changes in income inequality through heterogeneous dynamics of labor earnings of high-income and low-income groups. Heathcote, Perri, and Violante (2010) show that labor earnings at the bottom of the distribution are most negatively affected by economic downturns. This can be explained by the fact that employment losses fall disproportionately upon low-income groups, see, e.g., Jefferson (2008) and Carpenter and Rodgers (2004). To analyze whether employment dynamics can help to understand the debt-dependent distributional consequences, we investigate the effect of fiscal consolidations on aggregate employment, allowing again for different responses in high-debt and low-debt regimes. We do so by regressing, for each horizon, $k=0, \ldots, 4$, the change in the aggregate employment rate on our measure of fiscal consolidations and include lags of employment growth and output growth in the control vector $X_{i, t-1}$. If we find that the effects of the employment rate in response to fiscal consolidations differ across the credit cycle, the earnings heterogeneity channel offers an explanation for private debt-dependent inequality changes to austerity.

The results are shown in Figure 4. Notably, we only observe a significant fall in employment when private debt is high. At the end of the forecast horizon, the employment rate declines by more than 1 percentage point. The evidence described above suggests that this is associated with a disproportionate decline in employment for low-income groups that, in turn, translates into a rise in income inequality. In contrast, when private debt is low, the employment rate shows hardly any change in response to fiscal consolidations. Four years after the implementation of

\footnotetext{
${ }^{15}$ In classifying these channels, we follow Coibion, Gorodnichenko, Kueng, and Silvia (2012).
} 
the consolidation, the effect on the employment rate is almost zero. This may explain why we do not observe an increase in income inequality in periods when private debt is below trend.

The finding that job losses in response to fiscal consolidations are amplified by private indebtedness is related to theoretical contributions showing that the aggregate effects of fiscal policy interventions are larger during periods of private debt overhang, see, e.g., Eggertsson and Krugman (2012) and Andrés, Boscá, and Ferri (2015). The basic reason for why private debt elevates the effects of fiscal policy is the existence of borrowing-constrained households. Such households are characterized by a higher marginal propensity to consume out of income, compared to non-constrained households. If the share of these agents is large enough - which is positively related to the level of private indebtedness - Keynesian-type multiplier effects emerge.

Income composition channel. While, for most households, labor earnings are the primary source of income, others receive a larger share of their income from capital income. Low-income households typically rely on wage income, whereas high-income households tend to receive a relatively larger share of their income from capital income. When fiscal consolidations affect these different types of income heterogeneously, then the different household types experience different income outcomes. According to the income composition channel, a fall in the labor share of income in response to austerity affects poorer households' income relatively more strongly, which ultimately leads to an increase in income inequality.

To analyze whether different types of incomes are affected heterogeneously, we investigate the response of the labor share of income to fiscal consolidation shocks. We do so by re-estimating the regression model (1) but considering the change in the labor income share as the dependent variable. Thereby, the obtained estimation results allow us to detect the possible debt-dependent effects of austerity on the labor income share. We include lags of the labor income share together with real GDP growth in the control vector $X_{i, t-1}$.

As the second row of Figure 4 shows, fiscal consolidations affect different types of income in a heterogeneous manner. After fiscal consolidations, the labor share of income declines. As mentioned before, the relative decline in labor income primarily affects households in the lower part of the income distribution, generating a mechanism through which fiscal consolidations influence inequality. Turning to the role of private indebtedness, we see that the fall in the labor share is estimated to be strong and significant when austerity is implemented during a period when private debt high. The labor income share falls by more than 0.5 percentage points four years after the consolidation was implemented. When private debt is low, we only observe small and mostly insignificant changes in the labor share of income. At the end of the forecast horizon, the response of the labor share in low-debt states is less than half as strong as the response in 
Figure 4: Employment Rate, Labor Share, and Real Interest Rate.

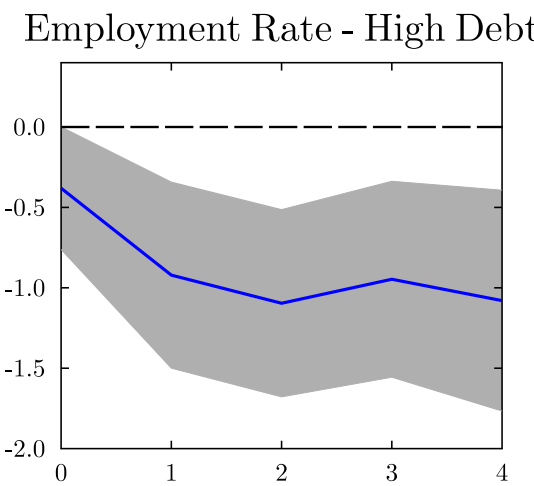

Employment Rate - Low Debt

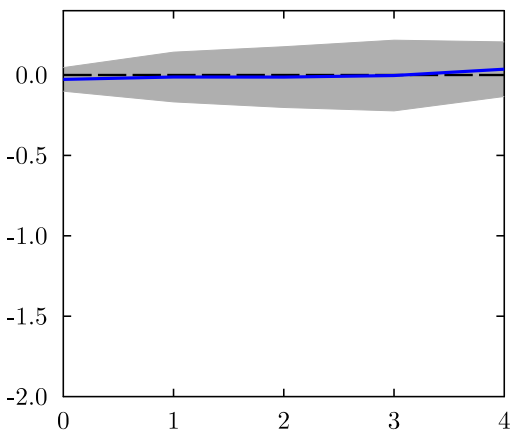

Labor Share - High Debt

Labor Share - Low Debt
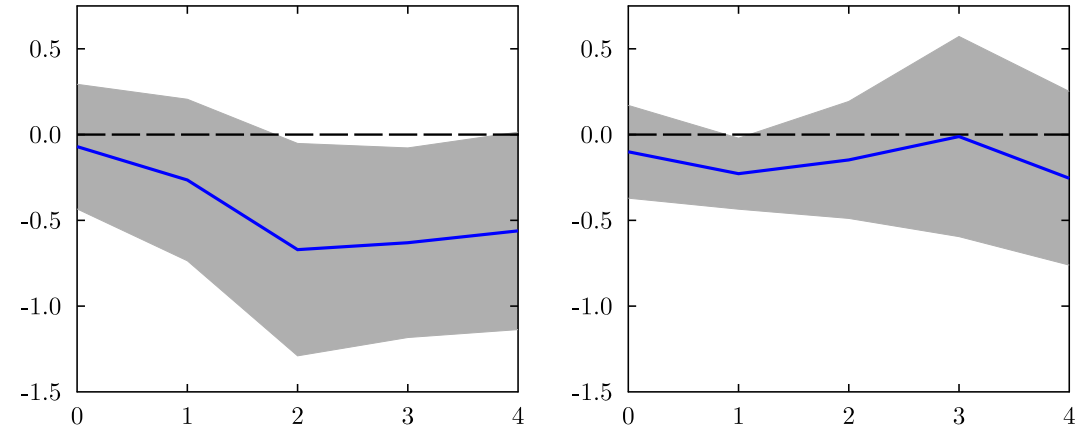

Real Interest Rate - High Debt

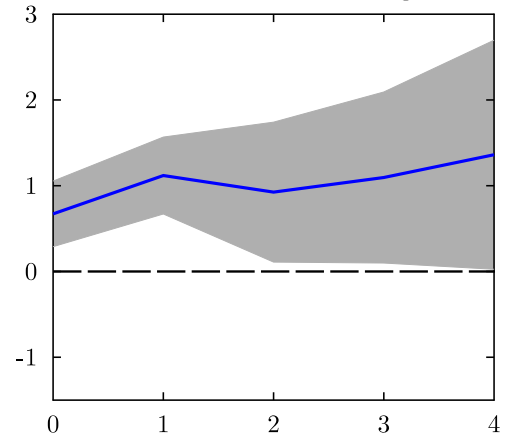

Real Interest Rate - Low Debt

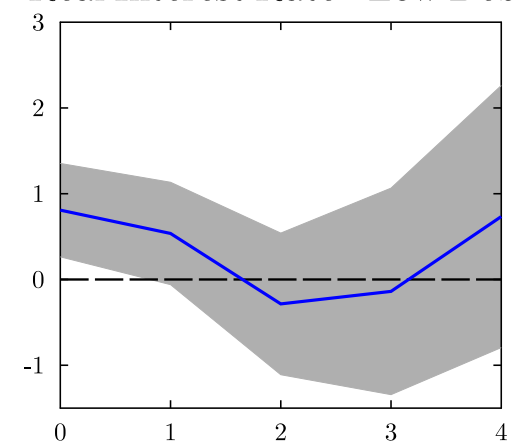

Notes: Changes in the respective variable in response to a shock of $1 \%$ of GDP to the cyclically-adjusted primary balance over $h=0,1,2,3,4$ years. The shaded areas indicate $90 \%$ confidence bands based on Driscoll-Kraay standard errors. 
high-debt states. Thus, as austerity has different effects on the labor share across the credit cycle, the income composition channel could be responsible for the debt-dependent inequality responses to fiscal consolidations.

Savings redistribution channel. An unexpected increase in real interest rates (through a rise in the nominal interest rate or a decrease in inflation) redistributes resources from borrowers to savers. Since borrowers are generally at the lower part of the income distribution, this generates a rise in income inequality. By studying nominal asset positions in the United States, Doepke and Schneider (2006) provide evidence for the importance of this channel. Moreover, Eggertsson and Krugman (2012) demonstrate that debt deflation is important for understanding the prolonged economic downturn that followed the latest financial crisis.

The last row of Figure 4 highlights the role of the savings redistribution channel for understanding our results. The figure shows results of an estimation exercise where we regress the change in the real interest rate on fiscal consolidation shocks, again adding the lag of the dependent variable to the vector of control variables. As seen in the figure, the real interest rate increases significantly when consolidations are implemented during high private debt periods. The increase in the real interest rate induces a rise in debt repayments that, according to the savings redistribution channel, positively affect income received by richer households. In contrast, when private debt is low, the real interest rate changes significantly only on impact, while for the remaining forecast horizons there is no statistically significant effect.

To summarize, we presented evidence indicating that the earnings heterogeneity channel, the income composition channel, and the savings redistribution channel all offer mechanisms through which private debt-dependent distributional consequences of fiscal consolidations can be rationalized.

\section{Conclusion}

This paper reveals important private debt-dependent effects of austerity. Estimating statedependent local projections for a panel of OECD countries, we provide evidence that the distributional consequences of fiscal consolidations vary considerably over the credit cycle. Fiscal consolidations lead to a strong and persistent increase in income inequality during periods of private debt overhang. By contrast, there are no discernible distributional effects when private debt is low. This finding is robust to taking into account possible anticipation effects, to different definitions of private debt overhang, to varying the sample period, and to controlling for the state of the business cycle. Private debt-dependent dynamics in aggregate employment, in the composition of income, and in real interest rates can help to understand our findings. 
Our results have important policy implications. Empirical evidence on the nonlinear effects of fiscal consolidations helps inform policy about the right time for austerity. According to our evidence, policy makers concerned about inequality should implement austerity measures when private debt is low. Conversely, our results suggest adverse distributional consequences of the large-scale austerity programs undertaken in the aftermath of the financial crisis where most countries were confronted with significant private debt overhang.

Our contribution also provides guidance for theoretical models that seek to study aggregate and distributional consequences of policy interventions. We show that private debt matters for the inequality effects of fiscal policy. Thus, the growing macroeconomic literature that integrates heterogeneous agents and distributional changes into New Keynesian models should elaborate on private indebtedness when studying the implications of fiscal policy interventions. Moreover, our results may help to differentiate between competing classes of heterogeneous agent models. Finally, the heterogeneity in income responses across households and the channels through which we try to explain the baseline findings may help to provide a better understanding of the transmission mechanism of fiscal policy.

\section{References}

Agnello, L. and R. M. Sousa (2014). How Does Fiscal Consolidation Impact on Income Inequality? Review of Income and Wealth 60, 702-726.

Alesina, A. and S. Ardagna (2010). Large Changes in Fiscal Policy: Taxes versus Spending. In Tax Policy and the Economy, Volume 24, NBER Chapters, pp. 35-68. National Bureau of Economic Research.

Alesina, A. and R. Perotti (1996). Income distribution, political instability, and investment. European Economic Review 40(6), 1203-1228.

Alesina, A. and D. Rodrik (1994). Distributive politics and economic growth. Quarterly Journal of Economics 109, 465-490.

Anderson, E., A. Inoue, and B. Rossi (2016). Heterogeneous consumers and fiscal policy shocks. Journal of Money, Credit, and Banking, forthcoming.

Andrés, J., J. E. Boscá, and J. Ferri (2015). Household Debt and Fiscal Multipliers. Economica 82, 1048-1081.

Auclert, A. (2016). Monetary Policy and the Redistribution Channel. Mimeo, Stanford University. 
Auerbach, A. J. and Y. Gorodnichenko (2012). Measuring the Output Responses to Fiscal Policy. American Economic Journal: Economic Policy 4, 1-27.

Auerbach, A. J. and Y. Gorodnichenko (2013). Output Spillovers from Fiscal Policy. American Economic Review 103, 141-46.

Ball, L. M., D. Furceri, D. Leigh, and P. Loungani (2013). The Distributional Effects of Fiscal Consolidation. IMF Working Papers 13/151, International Monetary Fund.

Barro, R. J. (2000). Inequality and Growth in a Panel of Countries. Journal of Economic Growth 5, 5-32.

Bernardini, M. and G. Peersman (2015). Private Debt Overhang And The Government Spending Multiplier: Evidence For The United States. Ghent Working Papers 2015/901, Ghent University.

Borio, C. (2014). The financial cycle and macroeconomics: What have we learnt? Journal of Banking \& Finance 45, 182-198.

Born, B., G. Müller, and J. Pfeifer (2015). Does Austerity Pay Off? CEPR Discussion Paper DP10425, Centre for Economic Policy Research.

Caggiano, G., E. Castelnuovo, V. Colombo, and G. Nodari (2015). Estimating Fiscal Multipliers: News From A Non-linear World. The Economic Journal 125, 746-776.

Carpenter, S. B. and W. M. Rodgers (2004). The disparate labor market impacts of monetary policy. Journal of Policy Analysis and Management 23, 813-830.

Castelnuovo, E. and P. Surico (2010). Monetary Policy, Inflation Expectations and The Price Puzzle. Economic Journal 120, 1262-1283.

Coibion, O., Y. Gorodnichenko, L. Kueng, and J. Silvia (2012). Innocent Bystanders? Monetary Policy and Inequality in the U.S. NBER Working Papers 18170, National Bureau of Economic Research.

Dell' Erba, S., T. Mattina, and A. Roitman (2015). Pressure or prudence? Tales of market pressure and fiscal adjustment. Journal of International Money and Finance 51, 196-213.

Devries, P., J. Guajardo, D. Leigh, and A. Pescatori (2011). A New Action-Based Dataset of Fiscal Consolidation. IMF Working Papers 11/128, International Monetary Fund.

Doepke, M. and M. Schneider (2006). Inflation and the Redistribution of Nominal Wealth. Journal of Political Economy 114, 1069-1097.

Drehmann, M., C. Borio, and K. Tsatsaronis (2011). Anchoring countercyclical capital buffers: the role of credit aggregates. BIS Working Papers 355, Bank for International Settlements. 
Drehmann, M., C. Borio, and K. Tsatsaronis (2012). Characterising the financial cycle: don't lose sight of the medium term! BIS Working Papers 380, Bank for International Settlements.

Driscoll, J. C. and A. C. Kraay (1998). Consistent Covariance Matrix Estimation With Spatially Dependent Panel Data. The Review of Economics and Statistics 80, 549-560.

Eggertsson, G. B. and P. Krugman (2012). Debt, Deleveraging, and the Liquidity Trap: A Fisher-Minsky-Koo Approach. The Quarterly Journal of Economics 127, 1469-1513.

Galbraith, J. K. and H. Kum (2005). Estimating the inequality of household incomes: A statistical approach to the creation of a dense and consistent global data set. Review of Income and Wealth 51, 115-143.

Gornemann, N., K. Kuester, and M. Nakajima (2016). Doves for the Rich, Hawks for the Poor? Distributional Consequences of Monetary Policy. International Finance Discussion Papers 1167, Board of Governors of the Federal Reserve System.

Guajardo, J., D. Leigh, and A. Pescatori (2014). Expansionary Austerity? International Evidence. Journal of the European Economic Association 12, 949-968.

Heathcote, J., F. Perri, and G. L. Violante (2010). Unequal We Stand: An Empirical Analysis of Economic Inequality in the United States: 1967-2006. Review of Economic Dynamics 13, $15-51$.

Hodrick, R. J. and E. C. Prescott (1997). Postwar U.S. Business Cycles: An Empirical Investigation. Journal of Money, Credit and Banking 29, 1-16.

Hofmann, B., G. Peersman, and R. Straub (2012). Time variation in U.S. wage dynamics. Journal of Monetary Economics 59, 769-783.

Jefferson, P. N. (2008). Educational attainment and the cyclical sensitivity of employment. Journal of Business and Economic Statistics 26, 526-535.

Jenkins, S. (2015). World income inequality databases: an assessment of wiid and swiid. The Journal of Economic Inequality 13(4), 629-671.

Jordà, O. (2005). Estimation and Inference of Impulse Responses by Local Projections. American Economic Review 95, 161-182.

Jordà, O., M. Schularick, and A. M. Taylor (2013). When Credit Bites Back. Journal of Money, Credit and Banking 45, 3-28. 
Jordà, O., M. Schularick, and A. M. Taylor (2016). Macrofinancial history and the new business cycle facts. In NBER Macroeconomics Annual 2016, Volume 31, NBER Chapters. National Bureau of Economic Research.

Jordà, O. and A. M. Taylor (2016). The Time for Austerity: Estimating the Average Treatment Effect of Fiscal Policy. Economic Journal 126, 219-255.

Kaplan, G., B. Moll, and G. L. Violante (2016). Monetary Policy According to HANK. NBER Working Paper 21897, National Bureau of Economic Research.

Kirschenmann, K., T. Malinen, and H. Nyberg (2016). The risk of financial crises: Is there a role for income inequality? Journal of International Money and Finance 68, 161-180.

Klein, M. (2016). Austerity and Private Debt. Journal of Money, Credit, and Banking, forthcoming.

Kumhof, M., R. Rancière, and P. Winant (2015). Inequality, Leverage, and Crises. American Economic Review 105, 1217-45.

Li, H. and H. Zou (1998). Income Inequality Is Not Harmful for Growth: Theory and Evidence. Review of Development Economics 2, 318-334.

Mian, A., K. Rao, and A. Sufi (2013). Household Balance Sheets, Consumption, and the Economic Slump. Quarterly Journal of Economics 128, 1687-1726.

Mumtaz, H. and A. Theophilopoulou (2016). The Impact of Monetary Policy on Inequality in the UK. An Empirical Analysis. Working Papers 783, Queen Mary University of London, School of Economics and Finance.

Owyang, M. T., V. A. Ramey, and S. Zubairy (2013). Are Government Spending Multipliers Greater during Periods of Slack? Evidence from Twentieth-Century Historical Data. American Economic Review 103, 129-34.

Persson, T. and G. Tabellini (1994). Is inequality harmful for growth? American Economic Review $84(3), 600-621$.

Ramey, V. A. and S. Zubairy (2014). Government Spending Multipliers in Good Times and in Bad: Evidence from U.S. Historical Data. NBER Working Papers 20719, National Bureau of Economic Research.

Schularick, M. and A. M. Taylor (2012). Credit Booms Gone Bust: Monetary Policy, Leverage Cycles, and Financial Crises, 1870-2008. American Economic Review 102, 1029-61.

Tenreyro, S. and G. Thwaites (2016). Pushing on a String: US Monetary Policy Is Less Powerful in Recessions. American Economic Journal: Macroeconomics 8, 43-74. 


\section{Appendix}

\section{A1 Data Definitions and Sources}

The baseline sample covers the period 1980-2011 and the countries Australia, Austria, Belgium, Canada, Germany, Denmark, Ireland, Spain, Portugal, France, Finland, United Kingdom, Italy, Japan, the Netherlands, Sweden and the United States.

Table A1: Data Definitions and Sources

\begin{tabular}{|c|c|c|}
\hline Variable & Definition & Source \\
\hline GDP, real & $\begin{array}{l}\text { Gross domestic product, constant prices, } \\
\text { OECD base year }\end{array}$ & OECD \\
\hline GDP, nominal & $\begin{array}{l}\text { Gross domestic product, current prices, cur- } \\
\text { rent PPPs, in US Dollar }\end{array}$ & OECD \\
\hline CAPB & $\begin{array}{l}\text { Cyclically-adjusted primary balance relative } \\
\text { to GDP }\end{array}$ & $\begin{array}{l}\text { Alesina and Ardagna (2010), } \\
\text { for 2010, } 2011 \text { OECD series } \\
\text { used }\end{array}$ \\
\hline $\begin{array}{l}\text { Narrative fiscal consolida- } \\
\text { tion measure }\end{array}$ & $\begin{array}{l}\text { Changes in fiscal policy motivated by a desire } \\
\text { to reduce the budget deficit and not by re- } \\
\text { sponding to prospective economic conditions }\end{array}$ & $\begin{array}{l}\text { Devries, Guajardo, Leigh, } \\
\text { and Pescatori (2011) and ex- } \\
\text { tended for the years 2010, } \\
2011\end{array}$ \\
\hline Income inequality (SWIID) & Gini coefficient for disposable income & $\begin{array}{l}\text { Standardized World Income } \\
\text { Inequality Database }\end{array}$ \\
\hline Income inequality (EHII) & Gini coefficient gross household income & $\begin{array}{l}\text { University of Texas Inequal- } \\
\text { ity Project }\end{array}$ \\
\hline Employment rate & $\begin{array}{l}\text { Civilian employment as \% population (15-64 } \\
\text { years old) }\end{array}$ & OECD \\
\hline GDP deflator & $\begin{array}{l}\text { Gross domestic product, deflator, index, hun- } \\
\text { dreds, base year } 2010\end{array}$ & OECD \\
\hline Total credit to private sector & $\begin{array}{l}\text { End-of-year credit to private non-financial sec- } \\
\text { tor from all sectors, market value, in US Dol- } \\
\text { lar, Adjusted for breaks }\end{array}$ & $\begin{array}{l}\text { Bank for International Set- } \\
\text { tlements }\end{array}$ \\
\hline Private debt-to-GDP ratio & $\begin{array}{l}\text { Total credit to private sector divided by GDP, } \\
\text { nominal }\end{array}$ & Own calculation \\
\hline Labor share & $\begin{array}{l}\text { Labor income share, real unit cots, total econ- } \\
\text { omy }\end{array}$ & OECD \\
\hline Unemployment rate & Unemployment rate as $\%$ of civilian labor force & OECD \\
\hline Interest rate & Short-term interest rate, per cent per annum & OECD \\
\hline Real interest rate & $\begin{array}{l}\text { Interest rate minus log difference of GDP de- } \\
\text { flator }\end{array}$ & Own calculation \\
\hline
\end{tabular}




\section{A2 Extension of the Narrative Measure}

In extending the narrative consolidation measure, we follow Dell' Erba, Mattina, and Roitman (2015), who provide data for the consolidation measure of 2010 and 2011. The extension of the dataset is based on the following two OECD reports: Restoring Public Finances, 2011 and Restoring Public Finances, 2012 Update. These reports outline the economic situation, fiscal consolidation strategy, and major consolidation measures for each OECD member country. The country notes in each report lay out each government's rationale for pursuing fiscal adjustment and are used to identify consolidation periods that were motivated by a desire for deficit reduction.

Table A2: Narrative Fiscal Shock, 2010-2011 (\% GDP)

\begin{tabular}{lll}
\hline \hline Country & 2010 & 2011 \\
\hline Australia & 0.00 & 0.00 \\
Austria & 0.00 & 0.90 \\
Belgium & 0.40 & 0.40 \\
Canada & 0.00 & 0.10 \\
Germany & 0.00 & 0.50 \\
Denmark & 0.00 & 0.90 \\
Finland & 0.20 & 0.30 \\
Spain & 2.70 & 2.20 \\
France & 0.00 & 1.10 \\
Ireland & 2.70 & 4.00 \\
United Kingdom & 0.60 & 1.20 \\
Italy & 0.00 & 0.90 \\
Japan & 0.00 & 0.00 \\
Portugal & 2.30 & 3.40 \\
Netherlands & 0.00 & 0.30 \\
Sweden & 0.00 & 0.40 \\
United States & 0.00 & \\
\hline
\end{tabular}




\section{A3 Smooth Transition}

The smooth transition results presented in Section 3.2 are obtained by estimating the following equation:

$$
\begin{aligned}
Y_{i, t+k}-Y_{i, t-1}= & F\left(z_{i, t-1}\right)\left[\beta_{H, k} D_{i, t}+\psi_{H, k} X_{i, t-1}\right] \\
& +\left(1-F\left(z_{i, t-1}\right)\right)\left[\beta_{L, k} D_{i, t}+\psi_{L, k} X_{i, t-1}\right]+\alpha_{i, k}+\eta_{t, k}+\epsilon_{i, t+k},
\end{aligned}
$$

where $F\left(z_{i, t}\right)$ is a smooth increasing function of an indicator of the state of the credit cycle. Following Tenreyro and Thwaites (2016), Auerbach and Gorodnichenko (2013) and Caggiano, Castelnuovo, Colombo, and Nodari (2015), we employ the logistic function

$$
F\left(z_{i, t}\right)=\frac{\exp \left(\theta \frac{\left(z_{i, t}-c\right)}{\sigma_{z}}\right)}{1+\exp \left(\theta \frac{\left(z_{i, t}-c\right)}{\sigma_{z}}\right)},
$$

where $c$ is a parameter that controls what proportion of the sample the economy spends in either private debt state and $\sigma_{z}$ measures the standard deviation of the state variable $z$. $\theta$ determines how violently the economy switches from a high-debt to a low-debt state when $z_{t}$ changes.

Given the mentioned evidence showing that the credit cycle has similar characteristics as the traditional business cycle (Jordà, Schularick, and Taylor 2016), we define $z_{i, t}$ following the approach of Tenreyro and Thwaites (2016), who study business cycle-dependent effects of monetary policy shocks. Thus, $z_{i, t}$ is defined as a two year moving average in the change of the private debt-to-GDP ratio. Moreover, $\theta$ and $c$ are set as in Tenreyro and Thwaites $(2016)(\theta=3, c=20)$. 